\title{
COMPARATIVE ANALYSIS OF THE CONTRACTS FOR MARITIME TRANSPORT SERVICES. CHAIN OF CHARTER PARTIES
}

\author{
Svetlana Dimitrakieva, Ognyan Kostadinov, Christiana Atanasova \\ Nikola Vaptsarov Naval Academy (Bulgaria)
}

\begin{abstract}
A basic principle in Law is the freedom of contract. Particularly, in Private Shipping Law, contractual parties may agree on all lawful terms and conditions which are most appropriate for the performance of the carriage. During the years of maritime trade practice, different types of contracts has been created, as well as systems of Chain Charter Parities have been adopted, through all of which the relations between maritime traders were settled. All this has contributed to maritime commercial practices for the carriage to be carried out not only by the shipowners, but also by other maritime traders with the appropriate authority and competence.

Keywords: maritime transport; charter party; liner bill of larding; voyage charter; time charter; bareboat charte; shipowners; disponent owners; carriers; charterers; commercial management; risks
\end{abstract}

\section{Introduction}

Nowadays, one of the most used contracts in the maritime scenario is the socalled charter party contract. (Zárate 2009) More than half of the world's shipping fleet is under a charter in one form or another. (Chen et al. 2021) Therefore, the interpretation of these obligations, rights, duties, liabilities, risks, earnings, costs, and profits between the contracted parties, namely, the shipowner and the charterer, as well as the understanding of charterparty terms, is considered of critical importance in chartering practice. (Plomaritou 2014)

Freight rate negotiations are a major factor in the maritime industry. In addition, the economic environment in which the shipping industry operates is characterized by high cyclicality, volatility, and unpredictability. The market has a high-risk profile. (Plomaritou et al. 2016) As an example, a ship can be chartered for $\$ 20,000$ a day on Monday, and on Friday the same type can be chartered for $\$ 30,000$ a day. If we set ourselves the task not to determine the values of the variables, but why they change, we can see that the model is dynamic, because supply and demand are determined separately, and the connecting link is the freight rate negotiations. The 
main task of the functioning market mechanism is not to determine freight rates, but to monitor the demand and supply of maritime services in a complex world in which shipping exists. In this article, we will look at how market participants can control the supply process.

\section{Contracts of carriage}

The most important documents governing the commercial and legal relationships between the parties in international sea transport are the bill of lading and the charter party. (Voudouris et al. 2020) The charter party is a legal contract of employing a vessel between the shipowner and the charterer. In shipping matters, charter parties and bills of lading are highly important documents since they allocate risks, obligations, rights, earnings, costs, and profits between the contracted parties, namely the shipowner (or carrier) and the charterer (or shipper). (Plomaritou et al. 2019)

Generally, the contracts for carriage of goods by sea are between carriers and shippers for the transportation of the contracted cargo by chartered vessel. There are two types of trip/voyage charters used in liners shipping and tramp shipping.

- Liner Bills of Lading are used in liner shipping for carriage of finished industrial goods.

- Voyage charter parties are used in tramp shipping for carriage of bulk and general cargoes, also for transportation of wet cargoes like all kind of oil, petroleum products, chemicals, and liquefied natural and petroleum gas, etc.

The contractual parties are:

- Contractor - the executor of the contract of carriage by sea or river vessel may be a shipowner (registered owner) or a sea carrier (disponent owner in private English Law) or a river carrier (carrier in EU Law).

- Contracting Authority - the contracting authority for the contract of carriage is the shipper in liner trade or tramp shipping - charterer or the end-charterer as per English law, if there is a chain of tenants (for example, registered owner - bareboat charterer - time charterer - voyage charterer).

The Contracts for hire of a vessel for a certain period of time are two types:

- Time-Charter Party - The Shipowners charter out the vessels with the crew for a certain period.

- Bareboat Charter Party - The Shipowners charter out the vessels without crew for a certain period.

The lessor is the registered shipowner who leases the ship on bareboat charter or time-charter. A lessor can also be a bareboat charterer, who subcontracts the vessel on time-charter. A lessor may be a time-charterer who subcontracts the ship or part of it on a time-charter to another sub time-charterer.

A tenant under a lease agreement can be a bareboat charterer, time-charterer, and sub time-charterer. 
According to the conditions of transport, there are two types of contracts:

- Contracts for carriage by sea in tramp shipping sector - voyage charter (voyage charter party) for the carriage of cargo between two or more ports, also for the transport of large quantities of goods on consecutive trips or several ships (Contract of affreightment).

Usual conditions of transport in the tramp shipping sector: Free In Out Stowed and/or Trimmed - the ship is loaded and unloaded free of charge for the carrier.

- Liner Shipping Contracts - Liner Bill of Lading - with incorporated terms and conditions in the Liner Bill of Lading, preceded by the relevant Booking Note, which is a reservation of space and place for a specific cargo.

Usual conditions of transport in Liner Shipping Sector: Liner In / Liner Out loading and unloading of the ship is on account of the carrier.

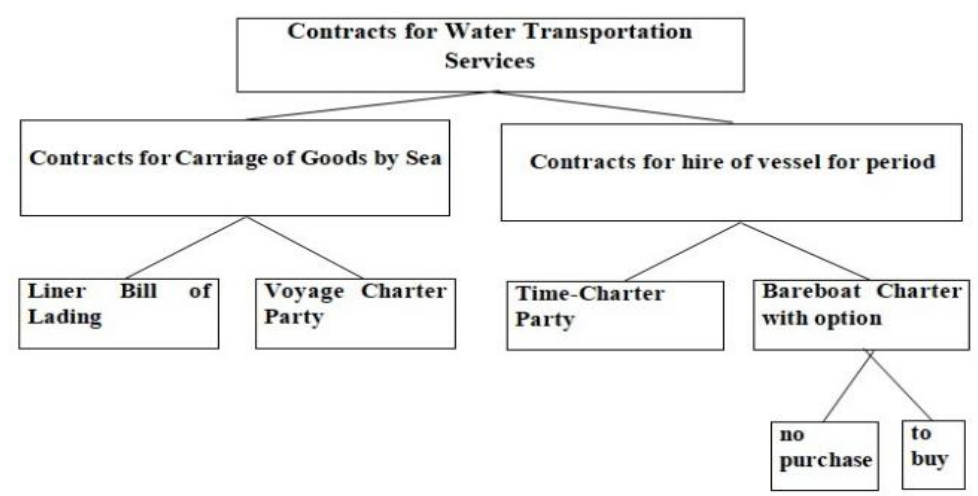

Figure 1. Structure of contracts for shipping services.

For each data situation, several approaches can be applied, each with its own assumptions and shortcomings. With the present analysis of the charter parties and liner trade contracts (Tables 1 to 17), however, we expect to shed some light on the mechanics that articulate this particular form of contract as a genre and on the interactions that take place between the dramatis personae that integrate it (Llopis 2014).

Table 1. Type of contract

\begin{tabular}{|l|l|l|l|}
\hline \multicolumn{1}{|c|}{ Bareboat C/P } & \multicolumn{1}{c|}{ Time C/P } & Voyage C/P & \multicolumn{1}{c|}{ Liner Trade Contracts } \\
\hline Contract for hire of a & Contract for hire & Contract & Liner transport contract, \\
ship for period without & of a ship for & for voyage & with all terms and conditions \\
crew, so called Bareboat & period with crew, & carriage & incorporated in the Liner \\
Charter or Demise & so called Time- & & Bill of Lading - used in \\
Charter. & Charter. & & traditional liner shipping. \\
\hline
\end{tabular}


Table 2. Subject of the contract

\begin{tabular}{|l|l|l|l|}
\hline \multicolumn{1}{|c|}{ Bareboat C/P } & \multicolumn{1}{|c|}{ Time C/P } & Voyage C/P & \multicolumn{1}{c|}{ Liner Trade Contracts } \\
\hline $\begin{array}{l}\text { Hiring a ship for a } \\
\text { certain period (usually } \\
\text { a long period of 5-10 } \\
\text { years), with or without a } \\
\text { purchase option. }\end{array}$ & $\begin{array}{l}\text { Hiring of a ship with } \\
\text { crew for a period, } \\
\text { for transportation } \\
\text { of cargo to the } \\
\text { lessee. }\end{array}$ & $\begin{array}{l}\text { Carriage of } \\
\text { goods by } \\
\text { sea or inland } \\
\text { waterways. }\end{array}$ & $\begin{array}{l}\text { Carriage of goods between } \\
\text { ports on the line maintained } \\
\text { by the Shipowner (registered } \\
\text { shipowner according to the } \\
\text { ship's Certificate of Registry) }\end{array}$ \\
\hline
\end{tabular}

Table 3. Application of the contract

\begin{tabular}{|c|c|c|c|}
\hline Bareboat C/P & Time C/P & Voyage C/P & $\begin{array}{c}\text { Liner Trade } \\
\text { Contracts }\end{array}$ \\
\hline $\begin{array}{l}\text { Usually used } \\
\text { as a tool } \\
\text { for deferred } \\
\text { payment when } \\
\text { buying a newly } \\
\text { built ship; It is } \\
\text { also used by } \\
\text { investors in } \\
\text { the shipping } \\
\text { business } \\
\text { who do not } \\
\text { directly engage } \\
\text { in maritime } \\
\text { transport } \\
\text { activities. }\end{array}$ & $\begin{array}{l}\text { The ship is chartered for } \\
\text { transportation of own } \\
\text { cargoes and other charterer } \\
\text { cargoes for commercial } \\
\text { purposes. It is common } \\
\text { practice in liner shipping } \\
\text { for combined transport } \\
\text { of intermodal units, liner } \\
\text { operators of containers, } \\
\text { trucks, and railway wagons, } \\
\text { to hire on Time-Charter } \\
\text { vessels to provide the } \\
\text { seaway of the transport } \\
\text { of their intermodal units. } \\
\text { Another broad application } \\
\text { of these contracts is the } \\
\text { time-chartering of vessels } \\
\text { by trading companies that } \\
\text { transport raw materials for } \\
\text { their production or goods } \\
\text { that they trade on the } \\
\text { international market. This } \\
\text { type of contract is also used } \\
\text { by speculators who hire } \\
\text { Time Chartered vessels in } \\
\text { a weak market, expecting } \\
\text { the market to improve, and } \\
\text { aiming to trade the ships } \\
\text { on the spot market by } \\
\text { transporting cargoes from } \\
\text { the market. }\end{array}$ & $\begin{array}{l}\text { Used in tramp } \\
\text { navigation for transport } \\
\text { of a specific cargo } \\
\text { between two or more } \\
\text { ports on the basis of } \\
\text { a single voyage. It is } \\
\text { possible to have an } \\
\text { additional partial load } \\
\text { of a second charterer. } \\
\text { A variant of this charter } \\
\text { is the contract for } \\
\text { a large amount of } \\
\text { cargo (Contract of } \\
\text { Affreightment), which is } \\
\text { transported in several } \\
\text { shipments for a certain } \\
\text { period, which can be } \\
\text { performed by one ship } \\
\text { on consecutive voyages, } \\
\text { or with several ships. } \\
\text { The contracts for a } \\
\text { large quantity, which are } \\
\text { transported in several } \\
\text { shipments for a certain } \\
\text { period, are used in } \\
\text { the provision of water } \\
\text { transport under annual } \\
\text { commercial contracts, } \\
\text { for the supply of raw } \\
\text { materials for a given } \\
\text { production. }\end{array}$ & $\begin{array}{l}\text { Used in Liner } \\
\text { Shipping. }\end{array}$ \\
\hline
\end{tabular}


Comparative Analysis of the Contracts for Maritime Transport...

Table 4. Lessor under the contract

\begin{tabular}{|l|l|l|l|}
\hline $\begin{array}{l}\text { Bareboat } \\
\text { C/P }\end{array}$ & \multicolumn{1}{|c|}{ Time C/P } & \multicolumn{1}{c|}{ Voyage C/P } & \multicolumn{1}{c|}{$\begin{array}{c}\text { Liner Trade } \\
\text { Contracts }\end{array}$} \\
\hline $\begin{array}{l}\text { Shipowner } \\
\text { (registered } \\
\text { shipowner } \\
\text { according } \\
\text { to the ship's } \\
\text { Certificate } \\
\text { or Registry). }\end{array}$ & $\begin{array}{l}\text { Shipowner (registered } \\
\text { shipowner according } \\
\text { to the ship's Certificate } \\
\text { or Registry). The } \\
\text { Lessor may also be } \\
\text { the Charterer of the } \\
\text { ship under the previous } \\
\text { charter of charter chain } \\
\text { if the ship previously } \\
\text { has been chartered out } \\
\text { without or with a crew. }\end{array}$ & $\begin{array}{l}\text { Shipowner (registered } \\
\text { shipowner according to the } \\
\text { ship's Certificate of Registry). } \\
\text { The Contractor (so called } \\
\text { Carrier) also may be the } \\
\text { Charterer of the ship under the } \\
\text { previous charter of the charter } \\
\text { chain if the ship previously has } \\
\text { been chartered out without or } \\
\text { with a crew (Bareboat Charter } \\
\text { and Time-Charter). }\end{array}$ & $\begin{array}{l}\text { Shipowner (registered } \\
\text { anipowner according to } \\
\text { the ship's Certificate of } \\
\text { Registry). It can also be } \\
\text { the Charterer of the ship } \\
\text { under the previous charter } \\
\text { of the charter chain if } \\
\text { the ship previously has } \\
\text { been chartered out on } \\
\text { Time-Charter or Bareboat } \\
\text { Charter. }\end{array}$ \\
\hline
\end{tabular}

Table 5. Lessee (tenant) under the contract

\begin{tabular}{|c|c|c|c|}
\hline Bareboat C/P & Time C/P & Voyage C/P & \begin{tabular}{|c|} 
Liner Trade \\
Contracts
\end{tabular} \\
\hline $\begin{array}{l}\text { The lessee under } \\
\text { the Bareboat Charter } \\
\text { is called Bareboat } \\
\text { Charterer - undertaking } \\
\text { company to which full } \\
\text { control, management and } \\
\text { responsibility for the ship is } \\
\text { transferred, with the right to } \\
\text { operate the ship and use her }\end{array}$ & $\begin{array}{l}\text { The tenant } \\
\text { under the } \\
\text { contract for } \\
\text { hiring the ship } \\
\text { with crew is } \\
\text { the so-called } \\
\text { Time- } \\
\text { Charterer. }\end{array}$ & $\begin{array}{l}\text { Called Charterers who are trading } \\
\text { companies and owners of goods } \\
\text { for transport by sea; forwarding } \\
\text { companies, who are engaged in the } \\
\text { complete transportation of goods } \\
\text { belonging to other charterers, } \\
\text { with several modes of transport; } \\
\text { brokers-speculators trading in } \\
\text { freight. }\end{array}$ & \begin{tabular}{|l} 
Direct \\
shippers \\
(traders and \\
exporters), \\
mainly \\
with small \\
numbers and \\
tonnage of \\
cargo.
\end{tabular} \\
\hline
\end{tabular}

Table 6. Contract Carrier

\begin{tabular}{|l|l|l|l|}
\hline $\begin{array}{l}\text { Bareboat } \\
\text { C/P }\end{array}$ & \multicolumn{1}{|c|}{ Time C/P } & \multicolumn{1}{c|}{ Voyage C/P } & \multicolumn{1}{c|}{$\begin{array}{c}\text { Liner Trade } \\
\text { Contracts }\end{array}$} \\
\hline $\begin{array}{l}\text { The } \\
\text { Bareboat } \\
\text { Charterer } \\
\text { under a } \\
\text { contract } \\
\text { (Bareboat } \\
\text { Charter) } \\
\text { for hire } \\
\text { of a ship } \\
\text { without a } \\
\text { crew. }\end{array}$ & $\begin{array}{l}\text { The shipowner (the } \\
\text { registered shipowner } \\
\text { according to the ship's } \\
\text { Certificate of Registry). } \\
\text { The Carrier also can be } \\
\text { the Charterer of the ship } \\
\text { on the previous charter of } \\
\text { the chain of charters if the } \\
\text { ship previously has been } \\
\text { chartered without crew or } \\
\text { with a crew. }\end{array}$ & $\begin{array}{l}\text { The shipowner (the registered } \\
\text { shipowner according to the } \\
\text { ship's Certificate of Registry). } \\
\text { The Carrier may also be the } \\
\text { Charterer of the ship under } \\
\text { the previous charter of charter } \\
\text { chain if the ship previously has } \\
\text { been chartered without or with } \\
\text { a crew (Bareboat Charter and } \\
\text { Time-Charter). }\end{array}$ & $\begin{array}{l}\text { The shipowner (the } \\
\text { registered shipowner } \\
\text { according to the ship's } \\
\text { Certificate of Registry). It } \\
\text { can also be the Charterer } \\
\text { of the ship under the } \\
\text { previous charter of the } \\
\text { charter chain if the ship } \\
\text { previously has been } \\
\text { chartered out on Time- } \\
\text { Charter or Bareboat } \\
\text { Charter. }\end{array}$ \\
\hline
\end{tabular}


Table 7. Carrier according to the transport documents (Bill of Lading)

\begin{tabular}{|c|c|c|c|}
\hline $\begin{array}{c}\text { Bareboat } \\
\text { C/P }\end{array}$ & Time C/P & Voyage C/P & Liner Trade Contracts \\
\hline $\begin{array}{l}\text { The lessee } \\
\text { (Bareboat } \\
\text { Charterer) } \\
\text { under the } \\
\text { Contract for } \\
\text { hire of a ship } \\
\text { without crew. }\end{array}$ & \begin{tabular}{l|} 
The \\
Shipowner \\
and the \\
Tenant \\
(Time \\
Charterer) \\
as agreed \\
in the \\
charter who \\
will appear \\
as carrier \\
on the \\
transport \\
documents \\
(Bill of \\
Lading).
\end{tabular} & $\begin{array}{l}\text { The shipowner (the } \\
\text { registered shipowner } \\
\text { according to the } \\
\text { ship's Certificate } \\
\text { of Registry). The } \\
\text { Carrier can also be } \\
\text { the Charterer of the } \\
\text { ship on the previous } \\
\text { charter of the charter } \\
\text { chain if the ship } \\
\text { previously has been } \\
\text { chartered out on } \\
\text { Time-Charter or } \\
\text { Bareboat Charter. }\end{array}$ & $\begin{array}{l}\text { The shipowner (the registered } \\
\text { shipowner according to the ship's } \\
\text { Certificate of Registry) when are } \\
\text { transporting cargo of a direct shipper } \\
\text { in traditional liner shipping or the } \\
\text { multimodal transport operator (MTO), } \\
\text { which has a multimodal transport } \\
\text { contract with the shippers and issues } \\
\text { a transport document for the whole } \\
\text { transport by sea and land route of the } \\
\text { cargo. In these cases, the Shipowner } \\
\text { is a subcontractor of the Multimodal } \\
\text { Transport Operator (MTO), with whom } \\
\text { they have the relevant contract, which } \\
\text { may be a Time Charter or a Voyage } \\
\text { Charter. }\end{array}$ \\
\hline
\end{tabular}

Table 8. Capital costs of the ship at the expense of:

\begin{tabular}{|c|c|c|c|}
\hline Bareboat C/P & Time C/P & Voyage C/P & Liner Trade Contracts \\
\hline $\begin{array}{l}\text { The Shipowner or } \\
\text { the Charterer under } \\
\text { a Contract for hire } \\
\text { of a ship without } \\
\text { a crew (Bareboat } \\
\text { Charter), if the } \\
\text { Contract has an } \\
\text { option for purchase } \\
\text { and respectively } \\
\text { the price of the } \\
\text { ship is included in } \\
\text { the leasing. If the } \\
\text { contract has no } \\
\text { purchase option, } \\
\text { then the capital } \\
\text { costs are at the } \\
\text { expense of the } \\
\text { Shipowner. }\end{array}$ & $\begin{array}{l}\text { The shipowner } \\
\text { (registered } \\
\text { shipowner } \\
\text { according to the } \\
\text { ship's Certificate } \\
\text { of Registry). The } \\
\text { capital costs may } \\
\text { also be borne by } \\
\text { the Charterer of } \\
\text { the ship under the } \\
\text { previous charter } \\
\text { chain if the ship } \\
\text { previously has } \\
\text { been chartered } \\
\text { without a crew } \\
\text { (Bareboat Charter } \\
\text { with option for } \\
\text { purchase). }\end{array}$ & $\begin{array}{l}\text { The shipowner } \\
\text { (registered } \\
\text { shipowner } \\
\text { according to the } \\
\text { ship's Certificate } \\
\text { of Registry). The } \\
\text { capital costs should } \\
\text { also be for the } \\
\text { Charterer of the } \\
\text { vessel under the } \\
\text { previous charter } \\
\text { of the charter } \\
\text { chain if the vessel } \\
\text { previously has been } \\
\text { chartered on Time- } \\
\text { Charter or Bareboat } \\
\text { Charter. }\end{array}$ & $\begin{array}{l}\text { The shipowner } \\
\text { (registered shipowner } \\
\text { according to the ship's } \\
\text { Certificate of Registry). } \\
\text { They can also be for the } \\
\text { Charterer of the ship on } \\
\text { the previous charter of } \\
\text { the chain of charters if } \\
\text { the ship previously has } \\
\text { been chartered out on } \\
\text { Bareboat Charter with } \\
\text { option to purchase the } \\
\text { vessel. }\end{array}$ \\
\hline
\end{tabular}


Comparative Analysis of the Contracts for Maritime Transport...

Table 9. Technical operation and fixed costs at the expense of:

\begin{tabular}{|c|c|c|c|}
\hline $\begin{array}{c}\text { Bareboat } \\
\text { C/P }\end{array}$ & Time C/P & Voyage C/P & Liner Trade Contracts \\
\hline $\begin{array}{l}\text { The lessee } \\
\text { (Bareboat } \\
\text { Charterer) } \\
\text { under a } \\
\text { contract } \\
\text { for hiring } \\
\text { of a ship } \\
\text { without } \\
\text { crew } \\
\text { (Bareboat } \\
\text { Charter). }\end{array}$ & $\begin{array}{l}\text { The shipowner } \\
\text { (registered shipowner } \\
\text { according to the ship's } \\
\text { Certificate of Registry) } \\
\text { or also may be the } \\
\text { Charterer of the ship } \\
\text { under the previous } \\
\text { charter of the charter } \\
\text { chain if the ship has } \\
\text { previously been } \\
\text { chartered out without } \\
\text { a crew (Bareboat } \\
\text { Charter). }\end{array}$ & $\begin{array}{l}\text { The shipowner } \\
\text { (registered shipowner } \\
\text { according to the ship's } \\
\text { Certificate of Registry), } \\
\text { also may be the } \\
\text { Charterer of the ship } \\
\text { under the previous } \\
\text { charter of charter chain } \\
\text { if the ship previously has } \\
\text { been chartered out on } \\
\text { Time-Charter or Bareboat } \\
\text { Charter. }\end{array}$ & $\begin{array}{l}\text { The shipowner } \\
\text { (registered shipowner } \\
\text { according to the ship's } \\
\text { Certificate of Registry). } \\
\text { It also may be for the } \\
\text { Charterer of the ship } \\
\text { under the previous } \\
\text { charter of charter chain } \\
\text { if the ship previously } \\
\text { has been chartered on } \\
\text { Bareboat Charter. }\end{array}$ \\
\hline
\end{tabular}

Table 10. Commercial operation and voyages at the expense of:

\begin{tabular}{|c|c|c|c|}
\hline Bareboat C/P & Time C/P & Voyage C/P & Liner Trade Contracts \\
\hline $\begin{array}{l}\text { The lessee } \\
\text { (Bareboat } \\
\text { Charterer) } \\
\text { under a } \\
\text { contract for } \\
\text { hiring a ship } \\
\text { without a crew } \\
\text { (Bareboat } \\
\text { Charter). }\end{array}$ & $\begin{array}{l}\text { The } \\
\text { charterer } \\
\text { under the } \\
\text { Contract for } \\
\text { hire of the } \\
\text { ship with } \\
\text { crew (Time } \\
\text { charterer). }\end{array}$ & $\begin{array}{l}\text { The shipowner } \\
\text { (registered shipowner } \\
\text { according to the ship's } \\
\text { Certificate of Registry), } \\
\text { also may be the } \\
\text { Charterer of the ship } \\
\text { under the previous } \\
\text { charter of charter chain } \\
\text { if the ship previously has } \\
\text { been chartered out on } \\
\text { Time-Charter or Bareboat } \\
\text { Charter. }\end{array}$ & $\begin{array}{l}\text { The shipowner (registered } \\
\text { shipowner according to the } \\
\text { ship's Certificate of Registry). } \\
\text { It also may be for the } \\
\text { Charterer of the ship under } \\
\text { the previous charter of charter } \\
\text { chain if the ship previously } \\
\text { has been chartered on Time- } \\
\text { Charter or Bareboat Charter. }\end{array}$ \\
\hline
\end{tabular}

Table 11. Loading and unloading of the ship and costs at the expense of:

\begin{tabular}{|l|l|l|l|}
\hline \multicolumn{1}{|c|}{ Bareboat C/P } & \multicolumn{1}{|c|}{ Time C/P } & \multicolumn{1}{c|}{ Voyage C/P } & \multicolumn{1}{c|}{ Liner Trade Contracts } \\
\hline $\begin{array}{l}\text { The lessee } \\
\text { (Bareboat }\end{array}$ & $\begin{array}{l}\text { The charterer } \\
\text { under the } \\
\text { Charterer) under a } \\
\text { contract for hiring } \\
\text { of a ship without } \\
\text { Crew (Bareboat } \\
\text { Charter). }\end{array}$ & $\begin{array}{l}\text { The carriage in Tramp } \\
\text { hiring of the ship } \\
\text { with crew (Time } \\
\text { shipping is usually } \\
\text { on FIO terms and the } \\
\text { costs are respectively } \\
\text { chat the expense of the } \\
\text { Shipper (Charterer) }\end{array}$ & $\begin{array}{l}\text { Contracted Carrier - } \\
\text { Shipowner (registered } \\
\text { shipowner according to } \\
\text { the ship's Certificate of } \\
\text { Registry) or Multimodal } \\
\text { Transport Operator } \\
\text { (MTO). }\end{array}$ \\
\hline
\end{tabular}


Table 12. Insurance of the ship H\&M at the expense of:

\begin{tabular}{|c|c|c|c|}
\hline Bareboat C/P & Time C/P & Voyage C/P & $\begin{array}{c}\text { Liner Trade } \\
\text { Contracts }\end{array}$ \\
\hline $\begin{array}{l}\text { The Bareboat } \\
\text { Chartererunder a } \\
\text { contract for hiring a } \\
\text { ship without a crew } \\
\text { (Bareboat Charter), but } \\
\text { the policy is issued in } \\
\text { favor of the shipowner. } \\
\text { But, when the charter } \\
\text { agreement has the } \\
\text { option to purchase } \\
\text { the ship, then the } \\
\text { insurance policy is } \\
\text { issued in favor of the } \\
\text { Shipowner and the } \\
\text { Lessee (Bareboat } \\
\text { Charter). }\end{array}$ & \begin{tabular}{|l|} 
The shipowner \\
(registered \\
shipowner \\
according to the \\
ship's Certificate \\
of Registry) or \\
also may be the \\
Charterer of the ship \\
under the previous \\
charter of the chain \\
of charters if the ship \\
previously has been \\
chartered out without \\
a crew (Bareboat \\
Charter).
\end{tabular} & $\begin{array}{l}\text { The shipowner } \\
\text { (registered } \\
\text { shipowner } \\
\text { according to the } \\
\text { ship's Certificate of } \\
\text { Registry), also may } \\
\text { be for the Charterer } \\
\text { of the ship under the } \\
\text { previous charter of } \\
\text { charter chain if the } \\
\text { ship previously has } \\
\text { been chartered out } \\
\text { on Time-Charter or } \\
\text { Bareboat Charter. }\end{array}$ & $\begin{array}{l}\text { The shipowner } \\
\text { (registered } \\
\text { shipowner } \\
\text { according to the } \\
\text { ship's Certificate } \\
\text { of Registry). It } \\
\text { also can be the } \\
\text { Charterer of } \\
\text { the ship on the } \\
\text { previous charter of } \\
\text { the charter chain if } \\
\text { the ship previously } \\
\text { has been chartered } \\
\text { Bareboat Charter. }\end{array}$ \\
\hline
\end{tabular}

Table 13. P \& I Club at the expense of:

\begin{tabular}{|c|c|c|c|}
\hline Bareboat C/P & Time C/P & Voyage C/P & $\begin{array}{c}\text { Liner Trade } \\
\text { Contracts }\end{array}$ \\
\hline $\begin{array}{l}\text { The Bareboat } \\
\text { Charterer } \\
\text { under a } \\
\text { contract for } \\
\text { Bareboat } \\
\text { Charter. }\end{array}$ & $\begin{array}{l}\text { The shipowner (registered } \\
\text { shipowner according to } \\
\text { the ship's Certificate of } \\
\text { Registry) or also may be } \\
\text { the Charterer of the ship } \\
\text { under the previous charter } \\
\text { chain if the ship previously } \\
\text { has been chartered out } \\
\text { without crew, also the } \\
\text { Charterer (Time charter) if } \\
\text { it is agreed to be carriers } \\
\text { on transport documents. }\end{array}$ & $\begin{array}{l}\text { The shipowner } \\
\text { (registered shipowner } \\
\text { according to the ship's } \\
\text { Certificate or Registry), } \\
\text { also may be for the } \\
\text { Charterer of the ship } \\
\text { under the previous } \\
\text { charter of charter chain } \\
\text { if the ship previously } \\
\text { has been chartered } \\
\text { out on Time-Charter or } \\
\text { Bareboat Charter. }\end{array}$ & $\begin{array}{l}\text { The shipowner } \\
\text { (registered } \\
\text { shipowner } \\
\text { according to the } \\
\text { ship's Certificate } \\
\text { of Registry), also } \\
\text { the Multimodal } \\
\text { Transport Operator } \\
\text { (MTO) if they } \\
\text { have issued the } \\
\text { transport document } \\
\text { for the goods. }\end{array}$ \\
\hline
\end{tabular}

Table 14. Adverse meteorological conditions at the expense of:

\begin{tabular}{|l|l|l|l|}
\hline \multicolumn{1}{|c|}{ Bareboat C/P } & \multicolumn{1}{|c|}{ Time C/P } & \multicolumn{1}{|c|}{ Voyage C/P } & $\begin{array}{l}\text { Liner Trade } \\
\text { Contracts }\end{array}$ \\
\hline $\begin{array}{l}\text { The Bareboat } \\
\text { Charterer under a } \\
\text { contract for hiring a } \\
\text { ship without a crew } \\
\text { (Bareboat }\end{array}$ & $\begin{array}{l}\text { The charterer } \\
\text { under the } \\
\text { Contract for hire } \\
\text { of the ship with } \\
\text { crew (Time- }\end{array}$ & $\begin{array}{l}\text { The shipowner (registered } \\
\text { shipowner according to the ship's } \\
\text { Certificate of Registry), also may } \\
\text { be for the Charterer of the ship } \\
\text { under the previous charter of }\end{array}$ & $\begin{array}{l}\text { The party } \\
\text { responsible } \\
\text { for } \\
\text { commercial } \\
\text { operation. }\end{array}$ \\
\hline
\end{tabular}


Comparative Analysis of the Contracts for Maritime Transport...

Charter), who are responsible for the commercial operation of the ship. charter) - who is charter chain if the ship previously responsible for has been chartered out on Timethe commercial operation of the ship.
Charter or Bareboat Charter who are the responsible party for commercial operation.

Table 15. Delay of the ship due to technical accidents and overconsumption of fuel at the expense of:

\begin{tabular}{|l|l|l|l|}
\hline \multicolumn{1}{|c|}{ Bareboat C/P } & \multicolumn{1}{|c|}{ Time C/P } & \multicolumn{1}{|c|}{ Voyage C/P } & $\begin{array}{l}\text { Liner Trade } \\
\text { Contracts }\end{array}$ \\
\hline $\begin{array}{l}\text { The Bareboat } \\
\text { Charter under } \\
\text { the Contract } \\
\text { for hire of a } \\
\text { ship without } \\
\text { crew (Bareboat } \\
\text { Charter), who } \\
\text { are responsible } \\
\text { for the technical } \\
\text { operation of the } \\
\text { ship. }\end{array}$ & $\begin{array}{l}\text { The shipowner } \\
\text { (registered shipowner } \\
\text { according to the } \\
\text { ship's Certificate of } \\
\text { Registry) or also may } \\
\text { be the Charterer of } \\
\text { the ship under the } \\
\text { previous charter of } \\
\text { the charter chain, if } \\
\text { the ship previously } \\
\text { was chartered out } \\
\text { without crew - who } \\
\text { are responsible for the } \\
\text { technical operation of } \\
\text { the ship }\end{array}$ & $\begin{array}{l}\text { The shipowner (registered } \\
\text { shipowner according to the } \\
\text { ship's Certificate of Registry), } \\
\text { also may be for the Charterer } \\
\text { of the ship under the previous } \\
\text { charter of the charter chain if } \\
\text { the ship previously chartered } \\
\text { out on Time-Charter or } \\
\text { Bareboat Charter who are the } \\
\text { party responsible for technical } \\
\text { operation. }\end{array}$ & $\begin{array}{l}\text { The party } \\
\text { responsible } \\
\text { for the } \\
\text { technical } \\
\text { operation. }\end{array}$ \\
& & \\
\hline
\end{tabular}

Table 16. Market risk for:

\begin{tabular}{|l|l|l|l|}
\hline \multicolumn{1}{|c|}{ Bareboat C/P } & \multicolumn{1}{|c|}{ Time C/P } & \multicolumn{1}{c|}{ Voyage C/P } & \multicolumn{1}{c|}{$\begin{array}{l}\text { Liner Trade } \\
\text { Contracts }\end{array}$} \\
\hline $\begin{array}{l}\text { The Bareboat } \\
\text { Charterer under } \\
\text { a contract for } \\
\text { hiring a ship } \\
\text { without a crew } \\
\begin{array}{l}\text { Bareboat } \\
\text { Charter), who are } \\
\text { responsible for } \\
\text { the commercial } \\
\text { operation of the } \\
\text { ship. }\end{array}\end{array}$ & $\begin{array}{l}\text { The charterer } \\
\text { under the } \\
\text { Contract for hire } \\
\text { of the ship with } \\
\text { crew (Time- } \\
\text { charter) - who is } \\
\text { responsible for } \\
\text { the commercial } \\
\text { operation of the } \\
\text { ship. }\end{array}$ & $\begin{array}{l}\text { The shipowner (registered } \\
\text { shipowner according to the } \\
\text { ship's Certificate of Registry), } \\
\text { also may be for the Charterer } \\
\text { of the ship under the previous } \\
\text { charter of charter chain if } \\
\text { the ship previously has been } \\
\text { chartered out on Time-Charter } \\
\text { or Bareboat Charter who } \\
\text { are the party responsible for } \\
\text { commercial operation. }\end{array}$ & $\begin{array}{l}\text { The shipowner } \\
\text { (the registered } \\
\text { shipowner } \\
\text { according to the } \\
\text { ship's Certificate } \\
\text { of Registry) or } \\
\text { the Multimodal } \\
\text { Transport Operator } \\
\text { (MTO) if the ship } \\
\text { is on their Time } \\
\text { Charter. }\end{array}$ \\
\hline
\end{tabular}


Table 17. Special notes

\begin{tabular}{|c|c|c|c|}
\hline Bareboat C/P & Time C/P & Voyage C/P & Liner Trade Contracts \\
\hline $\begin{array}{l}\text { The } \\
\text { ownership and } \\
\text { possession } \\
\text { of the ship } \\
\text { belongs to the } \\
\text { Shipowner, } \\
\text { but the ship } \\
\text { is held, } \\
\text { controlled, and } \\
\text { operated by } \\
\text { the charterer, } \\
\text { i.e. the } \\
\text { shipowner is } \\
\text { not responsible } \\
\text { for the ship. }\end{array}$ & $\begin{array}{l}\text { Ownership } \\
\text { and } \\
\text { possession } \\
\text { belongs } \\
\text { to the } \\
\text { Shipowner. } \\
\text { The tenants } \\
\text { (Time- } \\
\text { Charterers) } \\
\text { operate the } \\
\text { ship only } \\
\text { commercially } \\
\text { and exploit } \\
\text { it earning } \\
\text { capacity. }\end{array}$ & $\begin{array}{l}\text { The ownership and } \\
\text { possession of the ship } \\
\text { belongs to the Shipowner } \\
\text { (the registered shipowner } \\
\text { according to the ship's } \\
\text { Certificate of Registry). } \\
\text { The ship is under the full } \\
\text { control of the Shipowner } \\
\text { - the party responsible for } \\
\text { technical and commercial } \\
\text { operation. If there is } \\
\text { previous Charter of } \\
\text { Charter chain than the } \\
\text { Charterer under the } \\
\text { previous Time-Charter or } \\
\text { Bareboat Charter, they } \\
\text { will be responsible for the } \\
\text { ship. }\end{array}$ & $\begin{array}{l}\text { The ownership and possession } \\
\text { of the ship belongs to the } \\
\text { Shipowner. The ship sails on a } \\
\text { schedule in a pre-announced } \\
\text { line. The shipowner - the party } \\
\text { responsible for commercial } \\
\text { operation - books cargo, for } \\
\text { which it issues a Booking } \\
\text { Note. The contract of carriage } \\
\text { is formed upon acceptance of } \\
\text { the cargo by the liner agent, } \\
\text { who issues a Bill of Lading } \\
\text { or a Bill of Lading with the } \\
\text { general conditions of carriage } \\
\text { incorporated in it. If the ship } \\
\text { is sailing on a Time Charter } \\
\text { with the Multimodal Transport } \\
\text { Operator (MTO), then the latter } \\
\text { undertake to book cargo for } \\
\text { their intermodal transport unit. }\end{array}$ \\
\hline
\end{tabular}

Table 18. Structure and distribution of costs

\begin{tabular}{|c|c|c|c|c|c|c|c|c|c|c|}
\hline \multirow{2}{*}{\begin{tabular}{|c|c}
$\begin{array}{c}\text { Type of } \\
\text { the charter }\end{array}$ \\
On account of
\end{tabular}} & \multicolumn{2}{|c|}{ Liner Bill of Lading } & \multicolumn{2}{|c|}{$\begin{array}{l}\text { Voyage } \\
\text { Charter }\end{array}$} & \multicolumn{2}{|c|}{$\begin{array}{l}\text { Time- } \\
\text { Charter }\end{array}$} & \multicolumn{2}{|c|}{$\begin{array}{c}\text { Bareboat } \\
\text { Charter }\end{array}$} & \multicolumn{2}{|c|}{$\begin{array}{c}\text { Bareboat } \\
\text { Charter } \\
\text { with Sale }\end{array}$} \\
\hline & Shipowners & Charterers & $S$ & C & $S$ & C & S & C & $S$ & C \\
\hline Load \& disch exp. & $x$ & & & $\mathrm{x}$ & & $x$ & & $x$ & & $x$ \\
\hline Voyage exp. & $x$ & & $x$ & & & $x$ & & $x$ & & $x$ \\
\hline Running costs & $x$ & & $x$ & & $x$ & & & $x$ & & $x$ \\
\hline Capital exp. & $x$ & & $x$ & & $x$ & & $x$ & & & $x$ \\
\hline
\end{tabular}

Distribution of ship costs for different types of contracts for the carriage of goods by sea and charter of ships with or without crew (with and without the option to purchase the ship) are shown in Table 18. As can be seen from Table 18, the cost of the transport service, which is negotiated in the different types of contracts used in merchant shipping, is different. In this regard, the prices of different contracts for the carriage of cargo and the hire of ships are different. 
The commercial activity in water transport has a long history, complex character, and many traditions that have been created over the centuries. In principle, for the implementation of a transport service (transport), cargo and a ship are needed, as well as an assignor (a user of the transport service who pays the freight) and a contractor (carrier) who undertakes the obligation to transport the goods. For greater convenience and flexibility in trade, the practice has expanded the concepts of carrier and user of the transport service, also called the charterer, who is not always identified with the shipowner and shipper. The practice has required, where necessary, the obligations of shipowners regarding the operation of their ships to be transferred by contract to other persons, who are normally specialized maritime trading companies and merchants of goods traded by sea. In this regard, commercial activity in water transport is regulated by two categories of contracts - contracts for the hire of ships and contracts for the carriage of goods, also called charters. In the transport of one product, there can be only one active charter or more charters, forming the so-called Charter Party Chain. In cases where there is a chain of charters, then the shipowner concludes a charter with a tenant (so-called head charterer), who in turn concludes another charter with another tenant (sub-charterer).

Theoretically, there is no limit to the number of charters in the chain, i.e. there may be more than one sub-charterer. The last tenant (end-charterer) is the one who is the actual shipper and pays the freight for the transport.

\section{Conclusions}

A charterparty is a legal contract of chartering (employing) a vessel. It is a crucial shipping document since it allocates obligations, rights, duties, liabilities, earnings, risks, costs, and profits between the shipowner and the charterer. (Plomaritou 2014)

As the maritime industry embraces the digital age, computer science engineers are enabling important new capabilities, such as improved modeling, simulation, optimization, and automation, including machine learning. (Chen et al. 2021) The improvement and wider application of new technologies in every aspect of life have a significant impact on the development of maritime transport. The shipping industry has not yet adopted blockchain technology, but it should be borne in mind that it could be very useful in terms of organizing, tracking, and coordinating business transactions involving many parties.

One of the possibilities that can be fulfilled by blockchain technology is "smart contracts" - contracts in the form of a computer program, executed independently in a blockchain and automatically implementing the rules and conditions of each agreement between the parties, turning them into a standard part of the software without the possibility of change by the parties.

It is now possible to draw a conclusion that shortly many industries and businesses will face the reality of applying modern IT-based new management mechanisms that radically change the existing business models. (Molodchik, Dimitrakiev 2018; Molodchik et al. 2018) For this to happen, however, the most important aspects arising from charters in the main types of the charter must be mastered. 


\section{REFERENCES}

Chen, H., Ballou, P., 2021. Art and Science of Ship Voyage Optimization: A Critical Review. Available from: https://www.researchgate. net/publication/349289736_Art_and_Science_of_Ship_Voyage_ Optimization_A_Critical_Review. Last accessed: Apr 29, 2021.

Llopis, M. 2014. Contractual commitment, or obligation? The linguistic interactions in Charter Parties. Available from: https://www.researchgate. net/publication/271833021

Molodchik, A., Dimitrakiev, D., 2018. Digital Platforms as Factor Transforming Management Models in Businesses and Industries. International Conference Information Technologies in Business and Industry, 2018 IOP Publishing IOP Conf. Series: Journal of Physics: Conf. Series 1015 042040, doi:10.1088/1742-6596/1015/4/042040

Molodchik, A., Krutova, A., Elohova, I. \& Dimitrakiev, D., 2018. Models of platform economy. In: Proceedings of 11th International Conference Actual economy: local solutions for global challenges ACE-2018, 20- 23 [21.0324.03.2018].

Plomaritou, E., 2014. A Review of Shipowner's\& Charterer's Obligations in Various Types of Charter. Journal of Shipping and Ocean Engineering 4, 307 - 321.

Plomaritou, E., Nikolaidis, E., 2016. Commercial Risks Arising from Chartering Vessels. Journal of Shipping and Ocean Engineering 6, 261-268. doi: 10.17265/2159-5879/2016.05.001

Plomaritou, E., Voudouris, I., 2019. The Relationships of Bill of Lading, Charter party and Other Transport Documents. Journal of Economics, Management and Trade 24(6), 1-8, Article no.JEMT.51423. ISSN: 2456-9216.

Voudouris, I., Plomaritou, E., 2020. Documents of the Shipping Transport: Historical Origins, Legal Validity \& Commercial Practice. Journal of Shipping and Ocean Engineering 10, 47 - 56. Doi: 10.17265/2159-5879/2020.02.005

Zárate J., 2009. Risk of delay in charterparties: like a ping-pong game?REVIST@e - Mercatoria 8(1).

$\checkmark$ Svetlana Dimitrakieva

ORCID iD: 0000-0001-9639-9957

Ognyan Kostadinov

Christiana Atanasova

ORCID iD: 0000-0003-2102-037X

Nikola Vaptsarov Naval Academy Varna, Bulgaria

E-mail: sv.dimitrakieva@naval-acad.bg

E-mail: o.kostadinov@nvna.eu

E-mail:k.atanasova@nvna.eu 